\title{
EFEKTIVITAS PENGGUNAAN ROLE PLAYING UNTUK MENINGKATKAN KOMUNIKASI INTERPESONAL MAHASISWA
}

\author{
Ayong Lianawati \\ Program studi Bimbingan dan Konseling Universitas PGRI Adi Buana Surabaya \\ ayonglianawati17@gmail.com
}

\begin{abstract}
Abstrak
Komunikasi yang baik dapat meminmalisir kesalah pahaman, dan maksud serta harapan yang ingin dicapai bisa terwujud.Ketidak tepatan dalam berkomunikasi seperti penggunaan bahasa yang sarkas merupakan faktor utama yang menyebabkan maraknya bullying dan kekerasan verbal seperti saat ini.Role playing dapat melatih mahasiswauntuk berkomunikasi secara intepersonal dengan tepat. Penelitian bertujuan untuk menguji efektivitasrole playingdalam meningkatkan komunikasi interpersonal. Penelitianinimenggunakan metode quasi eksperiment one group pretes postes, yang dilakukan dalam seting bimbingan kelompok terhadap 7 orang sampel yang dipilih secara puposif. Hasil penelitian dan analisis data menggunakan uji $\mathrm{t}$ menunjukkan hasil yang siginifikan, thitung3.969 >lebih besar dari tabel 2.364, sehingga disimpulkan bahwa roleplaying efektif untuk meningkatkan komunikasi interpersonal mahasiswa.
\end{abstract}

Kata Kunci : Efektivitas, Roleplaying, Komunikasi Interpesonal

\section{PENDAHULUAN}

Berkomunikasi merupakan tuntutan penting di era saat ini, dan perlu dikuasai oleh mahasiswa. Keseharian mahasiswa selama proses belajar melibatkan kegiatan komunikasi baik diantara teman, dosen maupun steakholder lainnya. Komunikasi yang baik dapat meminmalisir kesalah pahaman, dan maksud serta harapan yang ingin dicapai bisa terwujud.

Komunikasi interpersonal adalah jenis kemampuan berkomunikasi yang berkaitan dengan peningkatan pergaulan di lingkungan perkuliahan maupun lingkungan rumah. Berkomunikasi menjadi media dan sarana untuk bergaul dengan teman sebaya. Mahasiswa yang kurang mampu mengembangkan keterampilan komunikasi interpersonal berakibat pada sulit memulai interaksi dan penyesuaian diri dengan lingkungan.

Secara sosial, komunikasi terutama komunikasi interpersonal berperan dalam mencegah terjadinya perilaku maladaptif seperti bullying. Hasil penelitian Usman (2013) menunjukkan selain iklim sekolah dan 
pertemanan, kemampuan komunikasi interpersona berperan besar pada situasi bullying yang marak terjadi. Ketidaktepatan dalam berkomunikasi seperti penggunaan bahasa yang sarkas merupakan faktor utama yang menyebabkan maraknya bullying dan kekerasan verbal seperti saat ini.

Beberapa penelitian menekankan pengembangan komuikasi interpersonal melalui kegiatan bimbingan kelompok. Bimbingan kelompok merupakan strategi bimbingan yang mampu memfasilitasi dalam mengemukakan pendapat, memahami dinamika sosial, dan beradaptasi dengan perbedaan individu di dalam kelompok. Oleh karena itu dinamika dalam bimbingan kelompok diperkirakan mampu mengembangkan cara berkomunikasi yang baik.

Dalam kajian ini teknik yang dipilih oleh penulis ialah roleplaying. Role Play merupakan metode alami yang merekomendasikan peserta melakukan proses penemuan melalui percobaan dan kesalahan. Dampak dari lemahnya kemampuan berkomunikasi antar peribadi akan dirasakan langsung oleh peserta, begitupun sebaliknya. Tujuan dari pengunaan role play adalah agar peserta dapat perlahan-lahan memperbaiki gaya berkomunikasi mereka berdasarkan analisa pada percobaan yang dilakukan dalam role play.

Keunggulan penggunaan teknik role play menurut Jackson (2011) adalah mempermudah dalam menciptakan keterlibatan, dan membuat komunikasi di kelas menjadi menyenangkan. Selain itu, ketika melakukan role play pendidik akan mudah menentukan waktu yang tepat dalam memberikan feed back yang menyenangkan (Dharmayanti, 2013).

Teknik role playing dapat dilakukan dalam berbagai dalam berbagai bentuk seperti sosiodrama, home room, berpantomim, bertukar peran, dan lain sebagainya. Beragamnya bentuk kegiatan yang menggunakan role playing memberikan banyak pilihan untuk penerapan bimbingan kelompok yang menyenangkan, dan sesuai dengan setiap aspek komunikasi interpesonal yang akan dikembangkan. Oleh karena dalam kajian ini dilakukan pengujian akan efektivitas role playing dalam meningkatkan komunikasi interpersonal.

\section{METODE}

Studi dilakukan dengan desain pre-eksperimen one group pretest-post test. Berdasarkan teknik puposif, diperoleh 3 orang skor tertinggi, 2 orang mahasiswadalam kategori rerata, dan 3 orang dalam kategori rendah sebagai sampel penelitian. 
Komunikasi interpersonal diukur menggunakan angket. Angket yang digunakan terdiri dari 25 item pernyataan, dan telah dikembangkan dari 5 aspek komunikasi interpersonal dari Devito yaitu: emphaty, openess, supportiveness, positiveness, dan equality.Pengukuran menggunakan skala likert.

Penelitian dilakukan di program studi Bimbingan dan Konseling Universitas PGRI Adi Buana Surabaya. Kegiatan intervensi dilakukan pada seting bimbingan kelompok terjadi dalam 3 sesi kegiatan.

Uji t-test dipilih sebagai teknik analisis data penelitian. Penggunaan t- test bertujuan untuk mengecek signifikansi perubahan skor dari kemampuan komunikasi interpersonal setelah dilakukan intervensi dengan menggunakan role playing. Pengolahan data dilakukan dengan menggunakan program SPSS.

\section{HASIL dan PEMBAHASAN}

Hasil

Berdasarkan data pretest dan posttest yang telah dikumpulkan diperoleh gambaran kemampuan komunikasi interpersonal seperti pada tabel 1 (Deskripsi skor kemampuan komunikasi interpersonal)

Tabel 1 .

Deskripsi skor kemampuan komunikasi interpersonal

\begin{tabular}{lcc}
\hline & Pre-test & Post Test \\
\hline Mean & 77.5 & 83 \\
Variance & 178.8571 & 109.7142857 \\
Nilai Minimum & 60 & 70 \\
Nilai Maksimum & 97 & 99
\end{tabular}

Hasil perolehan data pada tabel 1 menunjukkan adanya perubahan skor kemampuan komunikasi interpersonal setelah diberikan tiga kali treatment dengan teknik role play. Secara kuantitatif, perubahan skor rata rata dari kondisi pretes dengan posttest ialah 5.5 poin.

Untuk membuktikan perubahan signifikan tersebut maka dilakukan uji t (t-test) dengan menggunakan program SPSS. Hasil pengujian t-test disajikan pada tabel 2 berikut ini. 
Tabel 2

Pengujian t-test menggunakan SPSS.

\begin{tabular}{|c|c|c|c|c|c|c|c|c|}
\hline & \multicolumn{5}{|c|}{ Paired Differences } & \multirow[t]{3}{*}{$\mathrm{T}$} & \multirow{3}{*}{$\mathrm{df}$} & \multirow{3}{*}{$\begin{array}{l}\text { Sig. (2- } \\
\text { tailed) }\end{array}$} \\
\hline & \multirow[t]{2}{*}{ Mean } & \multirow[t]{2}{*}{$\begin{array}{c}\text { Std. } \\
\text { Deviation }\end{array}$} & \multirow[t]{2}{*}{$\begin{array}{l}\text { Std. } \\
\text { Error } \\
\text { Mean }\end{array}$} & \multicolumn{2}{|c|}{$\begin{array}{l}95 \% \text { Confidence } \\
\text { Interval of the } \\
\text { Difference }\end{array}$} & & & \\
\hline & & & & Lower & Upper & & & \\
\hline $\begin{array}{l}\text { Post Tes - } \\
\text { Pre Tes }\end{array}$ & 5,50000 & 4,20883 & 1,48805 & 1,98133 & 9,01867 & 3,696 & 7 & ,008 \\
\hline
\end{tabular}

Dari hasil perhitungan ujit ( $\alpha=$ 0,05, dk = 7) diperoleh thitung $=3,969$. Jika dibandingkan dengan $t_{\text {tabel, }}$ maka $t_{\text {thitung }}>t_{\text {tabel}}(3.969>2.364)$. Didukung dengan nilai signifikansi $<0.05$ yaitu 0.008yang menunjukkan adanya perbedaan yang signifikan antara pretest dengan posttest.Dengan demikiaan, role playingyang dilakukan terbukti efektif unutuk meningkatkan kemampuan komunikasi interpersonal.

\section{Pembahasan}

Secara signifikan komunikasi interpersonal mahasiswa meningkat setelah mengikuti role playing. Temuan penelitian sejalan dengan hasil penelitian Wicaksono (2013) yang sama sama membuktikan kemampuan komunikasi interpersonal responden berubah setelah dilakukan bimbingan dengan teknik bermain peran. Perbedaannya adalah pada penelitian tersebut menggunakan 6 sesi kegiatan.

Empati merupakan aspek utama yang dikembangkan dalam penelitian ini, dan menjadi aspek yang sangat penting dalam roleplaying, serta menentukan keberhasilan eksperimen. Faktor keberhasilan penerapan Role playing ditentukan oleh besarnya minat untuk memperhatikan masalah yang diajukan (Dharmayanti, 2013).

$$
\text { Penelitian Ruhani }
$$

menemukan bahwa bermain peran berdampak pada peningkatan keyakinan dan rasa percaya diri ketika berkomunikasi, serta menumbuhkan empati terhadap orang lain. Metode bermain peran melibatkan melibatkanpeserta untuk merasakan apa yang dirasakan dalam tokoh yang diperankan.

Sebagai komponen dalam keterampilan komunikasi interpersonal, empati terbukti mampu mengurangi kecenderungan dalam melakukan tindakan agresif. Gini, et al (2016) melakukan studi kepada 318 remaja di North of Italia yang terdiri dari 142 perempuan dan 176 laki-laki, mengenai agresi yang disebabkan oleh rendahnya empati. Studi menunjukkan pada kelompok lakilaki, perilaku bullying disebabkan oleh 
rendahnya tingkatan dari respon empati.

Role playing pada dasarnya melatih kemampuan dalam merespon perilaku dan sikap teman teman di sekitarnya. Bukan hanya berlatih untuk melakukan gaya komunikasi tertentu, namun juga berlatih menyelesaikan masalah yang dihadapi antar teman dengan cara berkomunikasi yang tepat serta tidak menyingggung perasaan.

Oleh karena itu, latihan role playing sangat tepat digunakan sebagai teknik dalam menyelesaikan persoalan komnikasi di lingkungan sekolah. Guru BK dapat memodifikasi cerita ataupun situasi yang menjadi tema dalam role playing menjadi lebih kontekstual sesuai dengan trend persoalan yang ada di sekolah, seperti menerima keragaman, salaing terbuka akan keinginan, dan berkomunikasi yang etis ketika berhadapan dengan usia yang berbeda. Sehingga hasil dari penerapan role playing dapat mempermudah untuk menciptakan iklim sekolah yang lebih kondusif.

\section{SIMPULAN}

Efektiftivitas roleplaying untuk meningkatkan komunikasi interpersonal mahasiswa telah terbukti baik secara empiris maupun statistik. Dilihat secara statistik terbukti berdasarkan hasil uji $t$, dengan thitung $>$ ttabelyaitu3.969>2.364.

Perubahan kemampuan komunikasi interpersonal meningkat secara signifikan pada signifikansi 0,05. Sehingga dengan demikian dapat disimpulkan bahwa teknik ini dapat digunakan untuk menyelesaikan persoalan komunikasi, terutama dalam melatih respon empati mahasiswa.

\section{REFERENSI}

DeVito, J.A. 2009. The interpersonal communication book. 12th edition. Hunter College of The City.

Dharmayanti, P. A. (2013). Teknik role playing dalam meningkatkan keterampilan komunikasi interpersonal siswa SMK. Jurnal Pendidikan dan Pengajaran, 46(3)

Gini, G., Albiero, P., Bonelli, B., \& Altoe, G. (2006). Does empathy predictadolescents' bullying and defending behavior ?. This is Preprint of an Article Accepted For Publication in Aggressive Behavior

Jackson, V.A. 2011. Teaching Communi-cation Skill Using RolePlay: An Experience-Based Guide For Educators. Journal of PalliativeMedicine. 14 (6): 775-780.

Ruhani, A. W. (2012). Upaya Meningkatkan Kemampuan Bersikap Toleransi Melalui Metode Bermain Peran Di Kelompok B Tk Batik Magersari Mojo Tahun Ajaran 2012/2013 (Ptk Kelompok B Tk Batik 
Magersari) (Doctoral dissertation, bimbingan kelompok untuk Universitas Muhammadiyah meningkatkan kemampuan Surakarta). komunikasi interpersonal siswa

Usman, I. (2013). Kepribadian, kelas $\mathrm{X}$ multimedia SMK IKIP komunikasi, kelompok teman Surabaya. Jurnal BK UNESA, 1(1). sebaya, iklim sekolah dan perilaku bullying. Humanitas: Jurnal Psikologi Indonesia, 10(1), 49-60.

Wicaksono, G. (2013). Penerapan teknik bermain peran dalam 